\title{
NYKYPÄIVÄN ODRADEK ELI "HUOMENNA ISÄ LEIKKII"
}

\begin{abstract}
JUSSI VÄHÄMÄKI: Itsen alistus. Polemos. Tutkijaliitto ja Like 2009.
\end{abstract}

\section{PERHEENISÄN OLOTILA}

Rien à faire (Estragon: En attendant Godot)

Yritän lukea olohuoneen sohvalla Jussi Vähämäen uutta kirjaa, jonka julkaisutilaisuuteen olen lupautunut keskustelemaan. Kaksi anovaa silmäparia tuijottaa minua ja korviini tunkeutuu pyyntönä esitetty vaatimus: "Isä kiltti, leiki meidän kanssa." Kieltäytyessäni pyytävän äänen sävy muuttuu yhä tuomitsevammaksi: "Isä ei halua leikkiä meidän kanssa." Tämä iskee jo tuon kuuluisan omatunnon kipinän, jonka sytyttämää syyllistävää roihua pyrin laimentamaan syyllisyyden vastatulia, työvelvoitteita luettelemalla. "Isän on nyt luettava tämä kirja, isä on luvannut mennä keskustelemaan siitä, isä leikkii sitten myöhemmin."

Lasten jaellessa isälle tuomioita isän olotila muuttuu yhä ärtyneemmäksi. Aivot eivät enää kykene keskittymään kirjaan, vaan hajamielisyyden tilassa niiden perukoilta nousee isän tajuntaan tajunnanvirran mestarin ja isänvallan klassisen kriitikon kirjan nimi: Oma huone. Siinä hävyttömien palvelijoiden ympäröimä Virginia Woolf esitti itsenäisen naisen tarvitsevan luovaan työhön suljetun porvarillisen interiöörin, oman tilan päästäkseen "hetkeksi pois yhteisestä olohuoneesta". ${ }^{1}$ Olohuoneen sohvalla kahden lapsen alla makaavasta isästä tuo Virginian toiselta vuosisadalta tuleva vaade tuntuu kohtuulliselta. Tosin isän luovaa aivotyötä jälkiteollisessa palveluyhteiskunnassa auttaisi muutama hävytön palvelijakin tai edes hitunen tuo- ta vanhaa surullisenkuuluisaa isänvaltaa, joka vuosituhansia muodosti kotitalouden järjestyksen itsestäänselvyyden. Tai kuten Vähämäki ilmaisi asian aristoteelisilla topoi-termeillä, tarvittaisiin kotitalouden argumenttien kiistämättömän yhteinen paikka. Perinteisesti tuo paikka ruumiillistui isän koskemattomassa ja siis pyhässä kotitalouden herran (despotes) ruumiissa. Tosin isän ruumiin asettama symbolinen auktoriteetti oli suurimmaksi osaksi läsnä kodissa vain poissaolonsa kautta ja varsinainen kotitalouden intiimi hallinto muodostui äidin läsnä olevan aistimellisen ja affektiivisen ruumiin ympärille.

Isän ruumis. Aikoinaan se oli Ernst Kantorowitzin analysoiman kuninkaan ruumiin tavoin symbolisen vallan kahdentama ja isän luonnollinen, kuolevainen ruumis siis erotettu patriarkan symbolisesta ruumiista. ${ }^{2}$ Vallaton nykyisän ruumis sen sijaan palautuu lähes kokonaisuudessaan isän rapistuvaan kuolevaiseen ruumiiseen, vaikka isä tekeekin symbolista tietotyötä taatakseen oman ja lastensa elävien ruumiiden biologisen uusintamisen. Mutta siinä missä äidin ja ylipäänsä naisen ruumis on saanut modernissa elävään ruumiiseen investoivassa "biovallassa" yhä enemmän huomiota, harva puhuu enää isän ruumiista. Isän ruumis on vallattomanakin edelleen tabu. Myös Vähämäki, jonka uuden kirjan hienoimmaksi teemaksi nousee juuri ihmisruumiin affektiivisen elävän työn kohtalot verkottuneessa ja lopulta täysin ruumiittomaan "aivottomaan ajatteluun" pyrkivässä tietokykykapitalismissa, mainitsee erityisesti vain naisruumiin korostaessaan sukupuolispesifiä naisten elävää hoivatyötä.

Isän ruumis. Tänään se on ollut koko päivän verkottuneena "tietopalvelutöissä" vastaamassa asiakasopiskelijoiden koulutustarpeisiin ja sitten keittiössä kotitöissä tekemässä ruokaa. Nyt se yrittää keskittyä luovaan ajatteluun tuossa $y h$ teisessä olohuoneessa, josta Virginia halusi saada luovan työn tekijät pois toteuttamaan omaa itseään omassa huoneessaan ja josta nykyinen tietoyhteiskuntamme haluaa saada isät ja äidit tuotannollisiin yhteistyöverkostoihin oman itsensä luovan toteuttamisen nimissä. Tällä hetkellä isän ruumis kuitenkin oleskelee olohuoneessa "äidin sohvalla" ja lukee Vähämäen nykyaikaisen tietotyöläisen mielentiloja ja työympäristön muutoksia ja vaatimuksia käsittelevää kirjaa kahden lapsen leikkiessä kirjaimellisesti isän ruumiin päällä. Kirjassa Vähämäki lainaa Giorgio Agambenin analyysia leikistä ja kosketuksesta tapana maallistaa pyhää, varastaa jumalilta aikaa ja ottaa se käyttöön. Isän tietotyöläisen ruumis ei tosin ole enää patriarkan pyhä ruumis vaan palkka- ja kotityössä hyödynnettävä jälkiteollisen yhteiskunnan ruumis, mutta samalla juuri jälkiteolliselle työlle pyhitetty ruumis. Juuri tuohon "pyhään" ruumiiseen lapset käyvät nyt käsiksi häiriten sen keskittymistä työasioihin ja pyrkien varastamaan sen aistimellista aikaa itselleen modernilta työn jumalalta.

Tehtävä on vaikea, sillä isä pyrkii edelleen eristämään aivonsa muusta ruumista tietotyöhön ja keskittymään Vähämäen vaativaan tekstiin, jonka mukaan "ymmärtääksemme mitä nykyaikaisessa yhteiskunnassa tapahtuu, on lähdettävä liikkeelle abstraktiosta, teoriasta tai virtuaalisesta ja edettävä siitä konkreettiseen ja aktuaaliseen" (s. 40). Isän pitäisi toki ymmärtää mitä yhteiskunnassa 
tapahtuu, onhan isä ammatiltaan yhteiskuntatieteilijä. Isän työ itsessään on yritystä ymmärtää mitä yhteiskunnassa tapahtuu, vaikka yhteiskunta itsessään ei ole siitä usein kovin kiinnostunut. Isä miettiikin, mistä yhteiskuntateoriasta olisi lähdettävä liikkeelle ymmärtääkseen, miten viime vuosisadan johtavan feministisen fiktion kirjoittajan konkreettisesti kokemasta isänvallasta ja omasta huoneesta on tullut konkreettiselle nykyperheenisälle teoreettinen abstraktio ja fiktio. Tässä kadotetun isänvallan nostalgian puuskassa perheenisä yrittää singota patriarkaalisia käskysanoja lapsille, mutta ne kimpoavat voimattomina takaisin vedoten moderneihin liberaaleihin sopimuksellisiin suhteisiin. "Eikö olla sovittu ettei työkirjoja lueta lasten läsnä ollessa." Niinpä niin, perheenisä ei ole enää lain lähde vaan lainsuojaton. Hän on liberaalin sopimuksen rikkoja, jonka vaade lukea omaa työkirjaa yhteisessä olohuoneessa voi näyttäytyä vain lakia kunnioittamattomana tyrannimaisena toimintana. Tyranni taas ei koskaan luo elävää lakia vaan tuottaa ainoastaan totuuden lausuvia marttyyrejä: "Leikitään kahdestaan, sisko leikkii sinun kanssasi, isä ei leiki meidän kanssa, isä tekee aina vain töitä."

\section{ARBEIT MACHT FREI}

Isä jatkaa kirjan lukemista, jossa Vähämäki kirjoittaa: "On surullista, mutta ilmeisen totta, että emme enää kykene leikkimään, koska teemme työtä aamusta iltaan ja illasta aamuun" (s. 172). Lapseni ja Vähämäki ovat eittämättä oikeassa, olen ollut aamusta asti töissä, nyt on ilta enkä ehdi leikkiä lasten kanssa, koska teen töitä. Samalla kuitenkin hajamielisesti "hoidan" myös lapsiani varsinaisesti näihin keskittymättä. Vähämäki taas korostaa hajamielisyyttä ruumiillisesti läsnä olevan elävän työn muotona. "Hajamielisinä käytämme tilaa aistimellisesti (kaikilla aisteillamme), ruumiillisesti (emme jollain elimellä) ja materiaalisesti. Mielemme on niin sanotusti toiminnassa, se tekee jotain olennaista, mutta se ei tee mitään erikoista." (S. 157.) Totta tosiaan, minun on oltava ruumiillisesti lasten kanssa läsnä, sillä eihän näitä voi vielä yksin jättää. Lasten äiti taas on kotitöistä "vapaalla" iltatöissä, siis "oikeissa" palkkatöissä niin sanotussa uudessa "luovassa taloudessa", ei tosin harjoittamassa itselleen ominaista luovuutta vaan istumassa hajamielisesti palaverissa. Minä taas luen koti- ja palkkatöiden muutosta luovassa tietokykykapitalismissa käsittelevää työkirjaa kotona olohuoneessa aistien samalla ruumiillisesti lasteni läsnäolon. Lapsilleni tämä hajaantunut ruumiillinen läsnäoloni ei kuitenkaan riitä, sillä vaikka isän ruumis on läsnä, tämän mieli on liikaa kirjassa. He haluavat isän mielen keskittyvän hic et nunc, heihin itseensä, he haluavat hengen ja ruumiin läsnä olevan yhteisön tässä ja nyt.

"Miksi se ei laita kirjaa pois", ihmettelevät pikku Vladimir ja Estragon, jotka odottaessaan äidin kotiintuloa eivät keksi mitään tekemistä ja haluavat isän viihdyttävän heitä. Tai kuten Vähämäki sanoisi, ilmaisevan heille, että maailma, jonka he aistivat, on todella olemassa. Mutta isällä ei ole aikaa aistia lasten maailmaa hic et nunc, koska hän on löyhässä pätkätyönarussa roikkuva tietotyöläinen, jonka pitää tuottaa monologeja yhteiskunnallisesta olemassaolosta Puncherin ja
Wattmannin tutkimusten mukaan blaa-blaa-blaa. Muuten hän menettää viimeisenkin luottonsa Pozzon kontrolloimilla akateemisilla tietomarkkinoilla, ja isähän on kuitenkin onnekas, niin sanottu Lucky, koska isällä on taas hetken aikaa oman alansa töitä, itse asiassa niin paljon, ettei isä oikeastaan ehdi tehdä mitään kuin hajamielisen levottomasti. Myös isä odottaa äidin tuloa, jotta hän voisi mennä työskentelemään niin sanottuun jälkiteolliseen työhuoneeseen eli tietokoneen ääreen. Jotta hän saisi viikon pätkätyöt tehtyä. Jotta hän voisi investoida uusiin töihin. Jotta hän saisi taas luottoa tietomarkkinoilla. Jotta hän voisi taas toteuttaa varsinaisia töitään. Jotta hän voisi kenties joskus päästä ihan oikeaan turvattuun vakituiseen palkkatyöhön. Jotta hänen ei tarvitsisi koko ajan olla huolissaan luotostaan. Jotta hänelle jäisi paremmin aikaa leikkiä lastensa kanssa. Niinpä niin, huomenna, huomenna, huomenna elämä alkaa, huomenna isä leikkii.

Tänään isä ei leiki vaan on kotitöissä sanan monissa merkityksissä. Keittiössä hurisee astianpesukone ja kylpyhuoneessa pyykkikone, mutta kuten Vähämäki kirjoittaa: "Tekniikan läsnäolo kotona ei vähennä oman erityisen kokemuksen, subjektiivisuuden ja persoonallisuuden osuutta kotityössä, vaan päinvastoin korostaa niitä: koneet ja laitteet eivät ole vähentäneet kotityötä, vaikka ne ovatkin 'henkistäneet' sitä. Ne ovat pikemminkin hajauttaneet entisestään kotityötä." (S. 156.) Isän mielestä isä on henkisesti kotitöissä, mutta lasten mielestä isä taas tekee kotitöitä sanan toisessa merkityksessä eli tekee kotona töitä, jotka heidän mielestään kuuluvat kodin 
ulkopuolelle. "Ei saa lukea kotona työkirjaa", he protestoivat ymmärtämättä, ettei isällä ole töissä aikaa lukea työkirjoja. Sillä vaikka oikeissa "palkkatöissä" isällä on "oma" huone, niin palkkaa isä saa ainoastaan työsuorituksista ja niihin ei lasketa tietämyksen kehittämistä kirjoja lukemalla vaan jo hankitun tiedon eli "tiedetyn" kommunikoinnista opiskelijoille, kollegoille ja yhteiskunnalle. Yhteiskuntatieteilijä-isä ei saa palkkaa siitä, että hän yrittäisi ymmärtää yhteiskuntaa. Hän saa palkkaa siitä, että hän kommunikoi kirjallisina tai suullisina suorituksina yhteiskunnallista ymmärrystään, joka hänen on hankittava varsinaisten palkkasuoritusten ulkopuolella. Kuten Vähämäki toteaa, palkkatyön kontrolloinnin mekanismit laskevat noita suorituksia. Niistä isä saa palkkansa, vaikka se on huomattavasti pienempi kuin niiden, joiden työn vaatimustasot eivät koske varsinaista tietotyötä vaan tuon tietotyön yhteiskunnallista hallinnoimista ja kontrolloimista. Isän on tietysti hankittava tietoa tietoyhteiskunnasta, hänen on hankittava tuota tietotyönsä varsinaista tuotantotekijää välittääkseen tuota tietoa muille. Tämän hankinnan on kuitenkin tapahduttava pienten apurahojen luotolla tai sitten se on vain isän omaa henkiseen pääomaansa investointia, jonka uuden inhimillisen pääoman talousteorian mukaan tosin pitäisi tuottaa isälle kasvavia palkkavirtoja. Mutta teoria ei takaa käytäntöä, ja vaikka isä investoi yötä päivää inhimilliseen pääomaansa, ei noita kasvavia palkkavirtoja näy käytännössä missään. Todellisessa tietoyhteiskunnassa, tässä ja nyt, tiedon hankkiminen ja luominen ei nimittäin lisää palkkavirtoja vaan ainoastaan tuskaa, kuten tieto aina. Vä- hämäki kirjoittaa taas totuudenmukaisemmin kuin yksikään informaatioajan konsultti: "Ristiriita, johon törmäämme ns. tietotaloudessa: tiedon keskeinen asema tuotannossa ja rikkauden luomisessa ei johda tietotyöläisten tulojen kasvuun, heidän asemansa varmuuteen ja yhteiskunnallisen arvostuksen lisääntymiseen, vaan päinvastaiseen tulokseen: tulojen pienentymiseen, työsuhteiden prekarisoitumiseen, yhteiskunnallisen arvostuksen laskemiseen" (s. 160).

Niinpä niin, kuuluisa tietoyhteiskunta ei ole yhteiskunta, jossa vaurastutaan tieto- tai aivotyöllä. Tosin ei maanviljelysyhteiskuntakaan ollut yhteiskunta, jossa vaurastuttiin maanviljelyllä vaan maata hallinnoimalla. Vähämäen ansiona onkin muistuttaa, että itsenäisen luovan tietoyrittäjän modernin ideaalin takaa pilkistää kurjistuva luovien tietotyöläisten joukko, aivan kuten pohjoismaisen vapaan talonpojan ideaalista on aina puhuttu enemmän kuin maatalousyhteiskuntien vuokratilallisten massoista. Tosin isäkin on vapaiden talonpoikien jälkeläinen ja haluaisi siksi olla vapaa tietotyöläinen. Isälle kuitenkin sanotaan toistamiseen hänen tietävän liikaa. Hän siis investoi liiallisesti tietämiseen, joka ei suinkaan ole tietoyhteiskunnassa hyve vaan pahe. Onkin suuri myytti, että tietoyhteiskunnassa arvostettaisiin tietoa. Tosiasiassa informaatioksi käsitetystä tiedosta on tietoyhteiskunnassa aivan liikaa tarjontaa ja siinä arvostetaan tuon tarjonnan rajaamista, siis informaation yhteiskunnallista hallintaa ja kontrollointia. Kuitenkin isä haluaisi uskoa vielä kauniiseen satuun sisällöllisen tietämyksen arvosta. Vähämäki kirjoittaa: "Meritokratia - haave siitä, että palkitaan ansioi- den mukaan - on aina ollut tietotyöläisen unelma. Tämä unelma elää edelleen vahvasti akateemisessa maailmassa, joka on sulkenut silmänsä työn muutoksilta, haaveilee itsepäisesti vanhoista hyvistä ajoista, puhumattakaan siitä, että se haluaisi luoda minkäänlaista silmäystä itse akateemisen työn rakenteellisiin ja sisällöllisiin muutoksiin, formalisoitumiseen tai esimerkiksi tutkintojen tason laskuun ja työn autonomian jatkuvaan supistamiseen." (S. 121.)

Vähämäki on varmasti oikeassa puhuessaan tiedon tuotannon autonomian rikkomisesta ja osuu myös oikeaan pilkatessaan isän kaltaisia akateemisia romantikkoja, mutta samalla Vähämäki tuntuu itse ostavan tietoyhteiskunnan myytin tiedon sinänsä positiivisesta tuottavuudesta, jota vallan negatiiviset kontrollimekanismit ainoastaan alistavat. Vaikka kirjan kahden luvun sisällön muodostaakin Michel Foucault'n uusliberalismiluentojen kommentointi, on Vähämäen yleinen tiedon ja vallan analyysi tässä suhteessa enemmän velkaa Vähämäelle itselleen läheisemmän ajattelijan, Gilles Deleuzen, ajattelulle kuin Foucault'n myös vallan tuottavaa positiivisuutta korostavalle ajattelulle. Toki myös Foucault kieltäytyi Deleuzen ja Vähämäen tapaan nostalgisoimasta valtamekanismien "vanhoja hyviä aikoja" uusia vallan muotoja analysoidessaan. Mutta on silti kysyttävä, onko akateemisten romantikkojen satu tiedon meritokratiasta vain menneisyyden myytti. Vai onko se kenties juuri satu satuna, siis tiedostettuna unelmana. Eikö Vähämäki kirjassaan puolusta juuri unelmien oikeuksia? Miksi sitten akateemiset romantikot eivät saisi unelmoida? Saduthan eroavat 
myyteistä juuri siinä, että ne tunnistetaan saduiksi. Mutta silti, tai kenties juuri siksi, saduilla voi olla myös kriittistä ja strategista voimaa osana nykyisyyden kritiikkiä. Yliopiston ylevät sivistyspuheet voidaan toki osoittaa ja tietää saduiksi ja toki niitä käytetään nykyään peittämään todellisen analyysin tarve. Mutta Platonin vanhan ohjeen mukaan satuja on kuitenkin kerrottava kansalaisille ja erityisesti aikamme ylimmälle auktoriteetille, abstraktille veronmaksajalle, jos edes jonkinlainen ajattelun itsensä kriittinen tila halutaan säilyttää. Modernilla tietotyöläisperheenisällä ei ole mitään halua palata "vanhoihin hyviin" aikoihin, jolloin isät olivat kotitöistä vapautettuja perheen kiistämättömiä patriarkkoja ja töissä tehtaissa tai toimistoissa kellokortin alaisuudessa. Ja kuitenkin yrittäessäni turhaan komentaa kahta lasta pois päältäni, että saisin luettua edes aloittamani kappaleen loppuun, en voi olla haaveilematta vanhasta Suomielokuvan kuvastosta, jossa äiti pyytää rauhallisesti leikkiviä lapsia olemaan vielä hiljempaa koska isällä on tärkeitä töitä.

\section{PERHEENISÄN HUOLI}

"Verkko, hän ajattelee sotkeutuneensa verkkoon." (Pozzo Luckystä)

Mutta tekeekö isä edes tärkeitä töitä? Mikä on tärkeää työtä? Isä itse oli lääkäriperheen lapsi ja siinä tehtiin tärkeitä töitä, ainakin jos asiaa kysytään "yleisesti tiedettyä" edustavalta yleiseltä mielipiteeltä. Kansan gallupeissa arvostetuimmista ammateista lääkärit nimitetään lähes aina tärkeän työn tekijöiksi. Biovallassa terveys korvaa pelastuksen ja yleinen tieto arvostaakin edelleen elä- vän ruumiin elämää. Lääkäreiden taas ajatellaan huolehtivan juuri tuosta elämästä. Lääkärin työn on myös perinteisesti nähty vaativan juuri kokemukseen perustuvaa läsnä olevaa elävää ruumiillista työtä. Tietoyhteiskunnassa tosin myös lääkärien keskeisin työväline on tietokone, tuo "postfordistisen kapitalismin työn symboli" (s. 34). Nykyään potilastietoja tietoverkkoon päivittävä lääkäri tuskin ehtii vilkaista potilaan elävää ruumista. Vähämäki huomauttaakin, että terveydenhuollon kustannusten vähentämiseksi on jo pitkään ollut pyrkimys formalisoida mahdollisimman paljon hoitoprosesseja. Keskeinen strategia terveydenhuollon, kuten muidenkin sosiaalisten kustannusten, karsimiseen taas on ollut juuri niiden vaatiman elävän työn tietoteknistäminen. "Informatisoinnin tavoitteena on fyysisen työvoiman tarpeen ja työntekijän ruumiillisen läsnäolon tarpeen vähentäminen tai eliminoiminen työssä" (s. 145). Kustannustehokkainta hoitoa on tietysti tilanne, jossa lääkärin ja potilaan "elolliset ruumiit" eivät kohtaa lainkaan ja jossa tuo lääkärin kuuluisa kliininen silmä, johon Foucault yhdisti modernin lääketieteen synnyn, voidaan korvata täysin potilaasta kerättyä informaatiota viimeisen lääketieteellisen tiedon valossa prosessoivalla tietokoneohjelmalla. Jäljelle jää toki edelleen alemman tason hoitotyö, tuo kirjaimellinen "paskaduuni", jossa suurten ikäluokkien pyllyn pyyhkimiseen tarvitaan yhä enemmän elävää halpatyövoimaa.

Gallupien kiistämättömän mielipiteen mielestä kaikkein vähiten tärkeää työtä taas tekevät poliitikot. Tämä ei lupaa kovin suurta arvostusta maailmanpolitiikan opettajana toimivan isän työlle. Tosin opet- tajia arvostetaan gallupeissa huomattavasti enemmän kuin esimerkiksi yritysjohtajia. Kansan valitsemat poliitikot ovat kuitenkin valmiit maksamaan yritysjohtajille kuukaudessa enemmän eläkettä kuin satoja yliopisto-opiskelijoita sadoista eri aiheista opettaneen isän koko vuoden vuositulot ovat. Yritysjohtajat ovatkin ainoa palkkatyöläisten luokka, johon yksilötasolla todella pätee poliitiikkojen edelleen hokema klassisen kansantaloustieteen ajatus työstä rikkauden lähteenä. Poliitikot ovat myös kansaa liberaalimpia työn tärkeyden suhteen, sillä heidän mukaansa "kaikki työ on tärkeää', tai kuten Vähämäki kirjassaan kiteyttää aikakauden poliittisen argumentaation kiistämättömän yhteisen paikan: "Tärkeintä on pelkkä työ, mikä tahansa työ" (s. 30). Tämän tähden kenen tahansa olisi otettava vastaan mitä tahansa työtä millä ehdoin tahansa. Vastaavasti poliitikot ovat valtio-omistajinakin valmiit maksamaan kenelle tahansa yritysjohtajalle mitä tahansa palkkaa tai luotottamaan näiden johtamia suuryrityksiä millä tahansa summilla, koska näiden uskotaan antavan ihmisille töitä. Ja mitä enemmän yritykset karsivat tuotantokustannuksia irtisanomalla kalliiksi tullutta elävää työtä, siis työntekijöitä, sitä enemmän usko yritysjohtajien tärkeyteen työn takaajina kasvaa.

Tosiasiassa tuo mikä tahansa työ ei tietenkään ole mitä tahansa työtä vaan verotuloja tuottavaa palkkatyötä. Toisin sanoen työtä, jonka joku tunnustaa työksi palkanmaksun kautta. Saadakseen armollisen työttömyyskorvauksensa työttömät vuorostaan eivät saa tehdä palkattakaan mitään palkkatyötä muistuttavaa, oli tämä sitten kuinka yhteiskunnallisesti hyödyllistä tahansa. 
Muutenhan voisi näyttää siltä, että yhteiskunta tunnustaisi tuon työn maksamalla siitä eräänlaista kansalaispalkkaa. Vielä vähemmän työttömät saavat tehdä mitään yrittämistä muistuttavaa eli investoida työttömyysaikansa kykyjensä ja projektiensa kehittämiseen, vaikka tämä valmistaisi heitä palaamaan tuotantoon. Muutenhan näyttäisi siltä, että yhteiskunta luotottaisi kansalaistensa itsensä tuottavia projekteja. Työttömyyskorvaus ei nimittäin ole kansalaispalkka vaan armollinen korvaus siitä, ettei henkilöllä ole palkkatyötä, jossa hän voisi kehittää itseään. Vastaavasti palkka tekee mistä tahansa toiminnasta työtä. Siitä lähtien kun inhimillinen toiminta nimeltä työ tuli markkinahyödykkeeksi, kaikki se, mistä työmarkkinoilla (kuinka suljetut tai avoimet tahansa nämä sitten sattuvat olemaan) maksetaan palkkaa, on ollut "oikeaa" työtä. Tämä huolimatta siitä, kuinka absurdilta tuo nykytyö näyttäisi muissa historiallisissa yhteiskunnissa ja muilla työmarkkinoilla "oikeaan" työhön liitettyjen piirteiden osalta.

\section{ABSURDI TYÖ}

Tuon "oikean työn" uusi absurdius on Vähämäen kirjan pohdintojen lähtökohta. Se käsittelee "oikean" palkkatyön muutosta tietokykykapitalismissa, jossa ihmiset palkkansa ansaitakseen tekevät asioita, joita ei liitetty työhön sen enempää maanviljelysyhteiskunnassa kuin teollisessa tehdasyhteiskunnassakaan. Itse asiassa kyse on usein työstä, jonka suhteen ei ole edes selvää, mitä ihmiset oikeastaan tekevät. Samalla kyse on tilanteesta, jossa palkkatyön ja muun elämän rajat tulevat yhä epämääräisemmiksi. Vaikka vain palkallinen aika katsotaan "oikeaksi" työksi, työn aika sekoittuu yhä enemmän elämän aikaan yleensä. Toisin sanoen me teemme työtä aamusta iltaan ehtimättä leikkiä lastemme kanssa, vaikka saammekin palkkaa vain hyvin pienestä osasta tuota työtä. Vähämäen ansiona onkin tehdä työn filosofiaa oudon uuden työn kokemuksen fenomenologiana. Hän pohtii työn ilmenemisen ja kokemuksen muutoksia, nykytyötä määrittävää ympäristöä ja sen vaatimaa virittyneisyyttä. Toisin sanoen hän käsittelee sitä työn tekemisen olotilaa, joka näyttäisi määrittävän myös olohuoneessa oleskelevan perheenisän tilaa.

Maailmanpolitiikan opettajan asemasta käsin Vähämäkeä olisi tietenkin helppo kritisoida muistuttamalla jälkiteollisen tietotyöläisen "kokemuksen" vielä suppeasta roolista globaalissa työnjaossa. Voisi muistuttaa siitä, kuinka tietotyöläisen absurdin kokemuksen osaksi mahdollistaa vähemmän verkottuneen globaalin "paskaduunin" alihankinta köyhemmistä maista. Mutta tällainen kritiikki olisi samalla yritys ohittaa puhe konkreettisesta uuden tietotyöläisen työn "paskamaisesta" kokemuksesta ja ongelmista hic et nunc, siis ohittaa "oman työelämän" poliittisuus ja korvata se taas tekopyhällä muiden (toisten) nimissä puhumisella. On selvää ettei Vähämäen kirja sen enempää ratkaise kuin avaakaan globaalin työnjaon tai työmarkkinoiden ongelmaa, mutta se kyllä puhuttelee aivotyötä tekevän jälkiteollisen tietotyöläisperheenisän lähes skitsofreenista kokemusta työstä. Se saa perheenisän myös pohtimaan, minkälaista työtä tämä Vähämäen kirjan lukeminen itsessään on? Siitähän kukaan ei varsinaisesti mak- sa isälle palkkaa. Tosin yhteiskunnallisen keskustelun seuraaminen voidaan katsoa yhteiskuntatieteilijän velvollisuudeksi ja vastaavasti kirjasta pidettävään keskustelutilaisuuteen osallistuminen yhdessä professoritason henkilöiden kanssa voidaan merkitä "työsuoritukseksi", pisteeksi niin sanotun yhteiskunnallisen vaikuttamisen kategoriaan.

Mutta minkälaista työtä Vähämäen lukeminen oikein on? Antiikista asti työ on liitetty tuotantoon. Työ on tuottavaa, se muuntaa ei-olevaa olevaksi. Vähämäen lukeminen on aina ajatuksellisesti tuottavaa. Vähämäen kirjat herättävät aina ideoita ja ajatuksia, oli niiden kanssa sitten samaa tai eri mieltä. Itse asiassa vielä enemmän silloin, kun niiden kanssa on epämääräisesti eri mieltä, sillä tämä pakottaa pohtimaan erimielisyyden syytä. Ne niin sanotusti pakottavat ajattelemaan yhdistäen klassisesti pakkoon liitetyn työn ja nykyään työhön liitetyn ajattelun. Vähämäen lukeminen on siis teoriassa tietoa tuottavaa aivotyötä. Hyvä niin. Mutta missä konkreettisessa mielessä tuo tieto olisi tuotantotekijä tietoyhteiskunnassa? Minkä rikkauden todellinen lähde se olisi? Tietenkin kyse on henkisen vaurauden lisääntymisestä, mutta juuri henkistä vaurautta arvostetaan yhä vähemmän niin sanotussa tietoyhteiskunnassa, ja yhteiskuntatieteilijänä voi kai sanoa, että juuri yhteiskunnallinen arvonmuodostus muodostaa yhteiskunnallisen vaurauden kriteerin. Tieto on kenties astunut neljänneksi tuotantotekijäksi, klassisten maan (fysiokraatit), työn (Smith ja Marx) ja pääoman (Schumpeter) lisäksi. Kenties se on ollut sitä aina. Mutta tekeekö tämä kaikesta abstraktista tiedosta konkreettista tuotantokykyä? Tällöinhän 
tietokykykapitalismin ongelma näyttäisi olevan vain tuon itsessään tuottavan tiedon kontrollointi, joka loppupeleissä on todelliselle tiedon tuotannolle vahingollista. "Tietokykykapitalismin suuri ongelma näyttäisi olevan se, onko tiedosta mahdollista tehdä tuottavaa muuten kuin rajaamalla, aitaamalla ja yksityistämällä tietoa, jos kerran on selvää että tiedon keinotekoisesti luotu niukkuus tuhoaa tiedon tuotantokykynä" (s. 106).

Selvältä näyttää. Mutta onko tämä lainkaan selvää? Jos etenemme abstraktista konkreettiseen, kuten Vähämäen kirja ehdottaa, niin abstraktista ajatuksesta tiedon yleensä tuottavuudesta voidaan toki johtaa ajatus jokaisen konkreettisen tiedon tuottavuudesta ja nähdä erilaiset tiedon rajaamiset vain tapoina estää tuon tuotannon ylitsepursuavaa itseilmaisua. Perheenisälle tämä kuitenkin tuntuu liian abstraktilta ajattelulta, samoin kuin kirjassa toistuva tiedon sinänsä käsite. Tämä siitä huolimatta, että myös perheenisä on huomannut, että tiedon hyödykkeeksi muuttumisen jälkeen on usein tärkeämpää tuottaa mitä tahansa informaatiohyödykkeitä kuin jotain erityistä tietoa. Perheenisä haluaisi kuitenkin edetä konkreettisesta abstraktiin ja kysyä, mistä ja minkälaisesta tiedosta ja tuotannosta on kulloinkin kyse. Tässä on kuitenkin mahdotonta alkaa syventyä tiedon ja tuotannon suhteiden ongelmiin, jota kirjan solmujen varsinainen setviminen vaatisi. Se, että jotakin on vaikea ajatella, ei tietenkään ole mikään vastaväite. Tiedetäänhän, että juuri paradoksit ja ristiriidat herättävät ajattelumme. Vähämäen tapana onkin asettaa ajattelumme haasteeksi paradokseja, jotka vaativat meitä kyseenalaistamaan annetut itsestäänselvyydet ja alkamaan ajatella. Näin tekee myös hänen uusin kirjansa Itsen alistus. Se kutsuu meitä ajattelemaan yhä abstraktimmaksi muuttunutta ajattelun ja työn ristiriitaista kokemusta tiedon ja yrittäjyyden ideaalin nimiin vannovassa yhteiskunnassamme. Vähämäken ansiona onkin olla yksi harvoista, jotka edelleen yrittävät ajatella juuri ajattelun, tiedon, yrittämisen ja tuotannon kokemusta tiedon tuotantoon varauksetta luottavassa nyky-yhteiskunnassamme.

Itsen alistus koostuu tuota kokemusta käsittelevistä puheenvuoroista, esitelmistä ja tekstinpätkistä. Vähämäki puhuu siitä kokoon kyhättynä sommitelmana ja vertaa sitä lempihahmoonsa, Kafkan Perheenisän huoli -novellista löytyvään omituiseen Odradekin hahmoon, jonka sarjakuvataiteilija Amanda Vähämäki on kuvannut tikkuun isketyksi viisisakaraiseksi naruvyyhdeksi. Kirja onnistuukin lähestymään nykypäivän Odradekia. Se koostuu useista nykyperheenisän huolessa yhteen kietoutuneista teemoista, mielialoista ja ajatuspätkistä, oli kyse sitten jatkuvasta kiireestä, syyllisyydestä, levottomuudesta, epävarmuudesta, hajamielisyydestä, odotuksista, henkisestä luototuksesta, kyynisten ja opportunististen mielialojen vaihtelusta, työn, kodin ja elämän sekoittumisesta, elävän ruumiin ja tietotyöläisverkoston suhteesta ja niin edelleen. Toisin sanoen se kuvaa verkostoa, jossa nykyperheenisä pyristelee ja jonka parempaa lupaavan pätkätyön ja kyykyttämisen liekanaru johtaa Pozzo-hämähäkkiin. Kirja myös lisää nykytyöelämän kafkalaiseen eläingalleriaan hyvin tunnistettavia käsitteellisiä henkilöitä. Tällainen on muun muassa nyky-ympäristössä erinomaisesti menestyvä ja lisääntyvä olio, joka ei ole valmis jakamaan tietoa vaan ennen kaikkea muuttamaan jaettua ja yhteistä tietoa yksityiseksi omaisuudeksi. Vähämäen mukaan kyseessä on " $Y h$ teistyöpersläpi (co-operation asshole), uusi selkärangaton hyönteinen, jolla on kova ja sileä kuori ja joka on sisältä täynnä pehmeää, vihertävää keltaista limaa" (s. 133). Niinpä niin, "kun Gregor Samsa eräänä aamuna heräsi levottomista unista, huomasi hän muuttuneensa vuoteessa suunnattomaksi syöpäläiseksi."”

Silti Itsen alistus ei ole parhaita Vähämäen tuotoksista. Sillä vaikka lähes kaikissa luvuissa on jälleen teräviä huomioita ja mainioita analyysipätkiä, jäävät useat niistä jotenkin keskeneräisiksi, ikään kuin kiireessä kirjoitetuiksi ja lopulta hieman sekaviksi siitäkin huolimatta, että Odradek itse on tietenkin sekavista pätkistä koostunut kerä. Näiltä osin perheenisä olisi toivonut lankojen vankempaa erittelyä pystyäkseen itse analysoimaan paremmin ympärilleen kietoutunutta verkkoa. Kirjassa on myös paljon toistoa. Se toistaa siinä itsessään itsestäänselvyytenä otettuja lähtökohtia ikään kuin tehden niistä näin lukijallekin itsestäänselvempiä. Toisaalta se toistaa myös Vähämäen aikaisemmista teoksista jo "tiedettyä", tosin hajanaisemmassa muodossa kuin esimerkiksi kokonaisuutena paljon tyylikkäämpi Kuhnurien kerho-teos.

Sokerina pohjalla on kuitenkin loppuluvun mainio ja loistavasti kirjoitettu lyhyt kertomus paskaduuneista ja rahoituskriisistä. Lukua voi suositella luettavaksi heti talousnobelisti Paul Krugmanin suuresti mainostetun Lama-kirjan samaa 
kriisiä käsittelevän loppuluvun jälkeen. Krugman mainostaa omaa kirjaansa epämuodollisen kepeällä, hauskalla otteella kirjoitettuna idearikkaana analyysina. Mutta kun kirjan on lukenut, huomaa, että sekä idearikkaus että kepeän hauska kirjoittaminen on luultavasti talousnobelisteille täysin mahdotonta. Krugmanin leikkisä ja "kansantajuistava" malli lamamekanismin toiminnasta on kongressin Capitol-kukkulalla työskentelevien lastenvahtitalous. Lopulta suosittaessaan julkisen talouden luotottavan kysyntää hän ehdottaa idearikkaasti sen luotottamisen suuntaamista "teihin, siltoihin ja muihin infrastruktuurihankkeisiin". ${ }^{4}$ Vähämäki ei tietenkään ole mikään talouden nobelisti, mutta miehellä on ainakin tajua aloittaa ihan oikeasti hauskasti kirjoitettu lamatarinansa slummien paskaduunareista.

1. Virginia Woolf, Oma huone. Kirjayhtymä 1980, 147.

2. Ernst H. Kantorowicz: The King's Two Bodies: A Study in Mediaeval Political Theology.
Hänellä on myös idearikkautta kysyä, josko kysyntää kasvattava luototus kannattaisi suunnata elävän ruumiin tuotantoon.

Mutta vaikka kirjan muissakin luvuissa on purevan satiirista yhteiskunta-analyysia, niiden heikkoutena on tuon satiirin muuttuminen välillä poleemisiksi heitoiksi fenomenologisesta lähikokemuksesta rakennettuja olkinukkeja vastaan. Nämä saavat usein ylikorostuneen merkityksen ja lukijan annetaan toisinaan ymmärtää, että nykytyön verkoston kutonut hämähäkki löytyisi ennen kaikkea yhteiskuntatieteiden laitoksilta tai tietyistä vasemmiston edustajista. Luulisin Vähämäen kuitenkin tarkoittavan, että edelliset ovat hänen mielestään kykenemättömiä purkamaan tuota verkostoa tai oletetuilla purkutöillään vain vahvistavat sen teräslankoja varmistaakseen, etteivät ihmi-

\section{$v$ i i t t e e t}

Princeton University Press. Princeton, NJ. 19573.

4. Kafka, Muodonmuutos. Teoksessa Kafka: Kootut kertomukset. Otava 1997. set putoaisi siitä kokonaan pois ja että hämähäkki saisi edelleen ravintonsa. Niin kauan kuin ihmisen perustava kutsumus on olla hämähäkin ruokaa, täydellinen verkon katkaiseminen ja sen aikaansaama vapaa pudotus näyttää tietenkin täysin utopistiselta ja kaikkien niiden uhrausten unohtamiselta, mitä "parempien asemien" saaminen verkossa on edellyttänyt. Siksi perheenisäkin lopettaa Vähämäen kirjan herättämien pohdintojen kutomisen tähän, jotta voisi tehdä "oikeat" palkalliset pätkätyöt, jotta saisi joskus "oikeita" palkattuja töitä, jotta voisi sitten saada myös "oikeaa" lomaa ja "oikeasti" leikkiä lasten kanssa. Niinpä niin, huomenna kun verkoissa kiipeilevä hämähäkkimies-isä on saanut Suuren Hämähäkin tunnustuksen: "Huomenna isä leikkii."

Markku Koivusalo

4. Krugman Paul, Lama. Talouskrisin syyt, seuraukset ja korjauskeinot. HS kirjat 2009, 197. 